\title{
ПРОФЕСІОНАЛІЗАЦІЯ ОСОБИСТОСТІ Й ФУНКЦІЙ НАУКОВО-ПЕДАГОГІЧНОЇ ДІЯЛЬНОСТІ СУЧАСНОГО ВИКЛАДАЧА В КОНТЕКСТІ АНДРАГОГІЧНОЇ ПАРАДИГМИ
}

\author{
Семенова О. Ю. \\ аспірантка кафедри педагогіки \\ Одеський національний університет імені I.I. Мечникова \\ вул. Дворянська, 2, Одеса, Украӥна \\ orcid.org/0000-0003-4428-1695 \\ kafedra.perevoda@gmail.com
}

\begin{abstract}
Ключові слова:
андрагогічна парадигма, професіоналізація

особистості викладача, комунікативно-рольовий репертуар, суб' 'кти науковопедагогічної діяльності, підготовка здобувачів вищчої освіти.
\end{abstract}

Стаття присвячена дослідженню проблеми професіоналізації особистості й функцій науково-педагогічної діяльності сучасного викладача закладу вищої освіти в контексті андрагогічної парадигми, яка розглядає здобувачів другого - магістерського - і третього - освітньо-наукового (докторського) - рівнів вищої освіти як дорослих, інтегральні, загальні й фахові компетентності яких формуються в процесі постдипломного навчання. Особлива увага приділяється обгрунтуванню положення, що інтеграція освітнього й наукового складників у діяльності закладів вищої освіти за умови орієнтації викладання на новітні наукові досягнення, використання їх у навчальному процесі, залучення здобувачів до дослідницької діяльності вимагає гнучкого використання різноманітних андрагогічних засобів, методів і форм, які спрямовані не на енциклопедичне засвоєння й накопичення знань багажного, застиглого, готового характеру, а на їх освоєння й видобування на кожному занятті в процесі діалогу всіх учасників освітнього процесу як інтелектуально розвинених, автономних і соціально зрілих суб'єктів освітніх відносин. Продемонстровано, що впровадження андрагогічної парадигми вимагає відповідної професіоналізації суб'єктів науково-педагогічної діяльності, які повинні стати провайдерами сучасних реформ у сфері вищої освіти на основі розширення й оновлення власного комунікативно-рольового репертуару як викладачів-тьюторів, коучів, фасилітаторів, едвайзерів, тренерів, менторів. Це дасть змогу суб'єктам науково-педагогічної діяльності бути експертами в галузі технологій навчання здобувачів вищої освіти як дорослих, організаторами спільної діяльності з ними, консультантами, натхненниками й співавторами індивідуальних програм навчання, а отже, джерелом знань і компетентностей. Отже, приєднання України до реалізації принципів Болонської декларації (утворення єдиного ринку праці вищої кваліфікації в Свропі, забезпечення якісного освітнього рівня фахівців і відповідності їх підготовки умовам міжнародного ринку праці) посилюе актуальність проблеми формування андрагогічної компетентності у викладацького складу науково-педагогічного персоналу вітчизняних закладів вищої освіти. 


\title{
PROFESSIONALIZATION OF A MODERN EDUCATOR'S PERSONALITY AND THEIR SCIENTIFIC AND PEDAGOGICAL ACTIVITY FUNCTIONS IN THE CONTEXT OF THE ANDRAGOGICAL PARADIGM
}

\author{
Semenova O. Yu. \\ Postgraduate Student at the Department of Pedagogics \\ Odesa National I. I. Mechnikov University \\ Dvorianska str., 2, Odesa, Ukraine \\ orcid.org/0000-0003-4428-1695 \\ kafedra.perevoda@gmail.com
}

\begin{abstract}
Key words:
andragogical paradigm, professionalization of educator's personality, communicative and role-playing repertoire, scientific and pedagogical activity subjects, training of higher education applicants.
\end{abstract}

\begin{abstract}
The article studies the issue of personality and scientific and pedagogical activity functions professionalization of a modern educator at higher education institutions in the context of the andragogical paradigm, which considers applicants for second-cycle (Master's level) and third-cycle of scientific and education $(\mathrm{PhD})$ level of higher education as adults who gain their integral, general, and specific competencies throughout their postgraduate training. It focuses on the arguing the statement that, provided that teaching is guided by the latest scientific achievements and their usage in the educational process, the integration of educational and scientific components in the activities of higher educational institutions and applicant's attraction to research activities require various and flexible andragogical tools, methods, and techniques. Their objective is not to assimilate and accumulate encyclopaedic knowledge of a complex, frozen, ready-made nature, but to develop and extract it after each lesson during the dialogue between all educational process participants who are intellectually developed, independent, and socially mature subjects of educational relations. It demonstrates that andragogical paradigm implementation requires appropriate professionalization of scientific and pedagogical activity subjects; they should be modern reforms providers in higher education relying on their own expanded and updated communicative and role-playing repertoire as tutors, coaches, facilitators, advisors, instructors, and mentors. This allows scientific and pedagogical activity subjects to be experts in technologies for teaching higher education applicants as adults, organizers of joint activities with them, advisors, inspires, and co-authors of individual training programs, and therefore, a source of knowledge and competence. It has been proved that Ukraine's adopting the Bologna Declaration principles (the formation of a common labour market with the highest qualification in Europe, the education level quality of experts, and their preparedness for the international labour market conditions) makes the issue of adragogical competence of the academic staff and teaching personnel at national higher education institutions even more topical.
\end{abstract}

Постановка проблеми. Проблеми глобалізації й цивілізаційних криз, які зумовлюють взаємодію молодого покоління 3 неусталеним соціумом XXI століття, що суперечливо розвивається під дією впроваджених соціально-економічних і соціокультурних перетворень у нашому суспільстві, потребують пошуку більш збалансованих шляхів модернізації вітчизняної системи вищої освіти, яка, дотримуючи болонських угод, у наступний час спрямована на підготовку здобувачів ступеня бакалавра, магістра та доктора філософії за відповідними спеціальностями згідно 3 Свропей- ською та Національною рамкою кваліфікацій [11]. Відповідно до провідних державних документів (Закони України «Про освіту» (1991), «Про вищу освіту» (2014), Державна національна програма «Освіта: Україна XXI століття» (1993), Національна доктрина розвитку освіти (2002), Стратегія розвитку «Україна - 2020» (2014), Концепція розвитку освіти України на період 2015-2025 pp.), підготовка здобувачів вищої освіти як соціальних замовників освітніх послуг і їхніх провідних інвесторів повинна бути спрямованою на задоволення їхніх інтелектуально-творчих, освітніх 
i соціокультурних потреб і професійних інтересів, а також на врахування, індивідуалізацію й розвиток особистісних якостей і здібностей [2]. Цьому більшою мірою сприятиме впровадження андрагогічної парадигми вищої освіти, яка в освітньому процесі закладу вищої освіти прискорює дорослішання студентів, надаючи їм більшої самостійності й автономності, свободи вибору й упевненості у своїх силах, відповідальності й лідерства в розвитку особистісного і творчого потенціалу, здатності до неперервного професійного зростання, мобільності й конкурентоспроможності на ринку праці [10, с. 51].

Мета статті полягає в обгрунтуванні доцільності професіоналізації особистості й функцій науково-педагогічної діяльності сучасного викладача закладу вищої освіти як педагога-андрагога шляхом опанування нових комунікативних ролей і розвитку відповідних дидактичних здібностей.

Виклад основного матеріалу дослідження. Перехід на андрагогічну парадигму підготовки здобувачів вищої освіти від традиційної - педагогічної моделі іï побудови у вищій школі, що відображує усталені стандарти освітніх програм, масово-репродуктивні методи навчання, пасивні форми організації пізнавальної діяльності студентів i слабко виражений практико-орієнтований характер навчальних дисциплін, ініціюе передусім зміну соціально-психологічного статусу сучасного студента, переміщуючи його роль 3 пасивного «отримувача» знань на активного здобувача певного рівня вищої освіти шляхом опанування необхідних ключових, загальних i фахових компетентностей [3, с. 57]. Отже, андрагогічна парадигма, ураховуючи те що сучасні демократичні зміни в суспільстві знань створюють кардинально інші можливості для студентів, визнає передусім їхнє право навчатися за гнучким навчальним планом (індивідуальній освітній траєкторії) 3 переважанням курсів за вибором, не тільки набути знання, а й розвити бажані компетентності, які забезпечують успішне вирішення професійно-практичних проблем, а також завдань неперервної освіти й самоосвіти.

Крім того, упровадження андрагогічних моделей підготовки здобувачів вищої освіти передбачає також розширення професійних функцій i ролей того, хто навчає. Якщо в педагогічній моделі викладач перебував більшою мірою в ролі «джерела» знань, то застосування андрагогічного підходу вимагає від того, хто навчає, бути експертом у питанні організації навчання дорослих, учасником спільної діяльності, організатором комфортних умов процесу навчання, «джерелом» не тільки знань, а й умінь, навичок, ставлень і ціннісних орієнтацій. Це передбачає, що викладач, який застосовує принципи андрагогічного підходу в професійній діяльності зі здобувачами вищої освіти, має володіти низкою спеціалізованих компетенцій i, ураховуючи різні ситуації взаємодії з ними в освітньо-науковому середовищі вищої школи, бути просвітителем, проповідником; монітором, наставником, радником, консультантом; тьютором, аніматором, медіатором, фасилітатором; проблематизатором; інтерпретатором; популяризатором, транслятором; координатором; майстром [4, с. 195].

Аналіз наукових джерел засвідчив недостатню розробленість цієї проблеми у вітчизняній науковій літературі, тому цінним для її розуміння $\epsilon$ думки зарубіжних учених:

- Д. Брауна, який систематизував комунікативні ролі викладача вищої школи як контролера, режисера, менеджера, фасилітатора, порадника. Ці ролі, на переконання вченого, найкраще можуть бути застосовані під час упровадження технологій інтерактивного навчання [8, с. 166-168];

- Д. Ренч, В. Річмонд, Д. Горен, які, описуючи дидактичні стратегії діяльності викладача, серед його провідних комунікативних ролей виділяють ролі лектора, модератора, тренера, менеджера, координатора, новатора [12, с. 28-42];

- Ю. Гібадулліної, яка, досліджуючи професійні позиції педагога в освітньому процесі закладу вищої освіти, систематизувала такі його ролі: методист, менеджер, інноватор, ментор, супервізор, мотиватор. Натомість найбільш важливими для професійної діяльності викладача закладу вищої освіти дослідниця вважає чотири ролі: роль викладачів як трансляторів знань трансформується в їхню місію як тьютора, модератора, фасилітатора, дослідника [1, с. 26-36].

На думку означених авторів, різні комунікативні ролі та дидактичні стратегії викладача спрямовані на організацію діяльності студентів, їх підтримку й супровід на різних етапах освітнього процесу залежно від цілей навчання. При цьому науковці стверджують, що залежно від мети освітньої діяльності й рівня підготовки студентів викладач як андрагог може вибрати для себе будь-яку домінуючу роль. Проте він повинен намагатися відійти від великої кількості директивних указівок і виховних настанов, щоб звільнити студентів від повної залежності (від викладача, підручника, плану заняття тощо), підвищити внутрішню мотивацію й освітній рівень студентів.

Зокрема, викладач-андрагог як фасилітатор допомагає здобувачам вищої освіти почути й зрозуміти один одного під час дискусій, полегшуючи процес інформаційно-комунікативної взаємодії. Він повинен уміти структурувати процес спілкування, перефразовувати ідеї учасників дискусії для їх кращого розуміння й обговорення, керувати процедурою взаємодії, вчасно проводити основні 
висновки $з$ дискусії або групової роботи. При цьому роль фасилітатора, спрямована на здійснення спеціального виду педагогічної діяльності 3 організації навчання, зводиться не для не обміну інформацією та знаннями $[6$, с. 10]. Фасилітатор $є$ скоріше супровідником навчальної групи в їхньому особистому розвитку, оскільки він заохочує здобувачів ділитися своїми ідеями, ресурсами й думками, мислити критично, щоб розв'язати певну проблему, дійти спільного рішення, підвищити майстерність. Фасилітатор не бере прямої участі в обговоренні проблеми, але несе відповідальність за якісне виконання завдання.

Медіація, або посередництво, може бути затребуваною як уміння викладача-андрагога організовувати такі форми занять, як «доповідь-опанування», де одна частина групи готовить групову доповідь на певні теми $[1$, с. 89]. Медіатор заздалегідь знайомить іншу частину групи із цією доповіддю для опанування під час захисту й опанування власної експертної думки стосовно обговорених питань, регулює взаємодію учасників як посередник, запобігаючи конфліктній ситуації й поліпшуючи тим самим морально-психологічний клімат, забезпечуючи комфортні умови перебування здобувачів вищої освіти в групі.

Роль викладача-андрагога як модератора ініціативна та спрямована на розвиток активності здобувачів вищої освіти як провідних учасників освітнього процесу. Модератор повинен уміти сформувати завдання для обговорення в проблемній формі, що викликає інтерес здобувачів і бажання іiї обговорити [4, с. 93]. Він виявляє й формулює протиріччя в ідеях і пропозиціях здобувачів для активації дискусії, виступаючи в ролі «двигуна» змістової інтелектуально-творчої взаємодії.

Як закономірний наслідок, андрагогічна парадигма вищої освіти відповідно до структурованих освітньо-професійних та освітньо-наукових програм здобувачів ступеня магістра й доктора філософії як дорослих суб'єктів освітнього середовища фіксує зміну та необхідність переведення дидактичного функціоналу викладача на стиль «відносин підтримки, супроводу й допомоги» [6, с. 9], режим взаємодії зі студентами на засадах «академічної свободи», «партнерства», «діалогу культур» [7, с. 48], що зумовлює використання інтерактивних форм занять із застосуванням новітніх освітніх технологій і засобів. Тому основними функціями професійної діяльності викладача як андрагога, який взаємодіє зі здобувачами вищої освіти як дорослими суб'єктами освітньо-наукового середовища, $€$ такі:

- визначальна функція, що пов'язана з допомогою здобувачам щодо вибору профілю освітньої програми;
- планувальна функція, що зводиться до проектування способів організації процесу навчання й проектування індивідуальних освітніх маршрутів здобувачів;

- мотиваційна функція, спрямована на створення сприятливих для навчання здобувачів психолого-педагогічних умов;

- методична функція, націлена на вибір найпродуктивніших методів і технік навчання, доцільних для успішного проходження навчального плану;

- функція залучення, що передбачає добір і використання матеріально-технічних ресурсів та інформаційно-комунікативних засобів, необхідних для здійснення ефективного навчання здобувачів як дорослих;

- оцінна функція, спрямована на гармонізацію оцінки академічних досягнень здобувачів і самооцінки ними результатів навчання [9, с. 125].

Варто зазначити, що серед вимог, які висуваються до особистості викладача-андрагога, котрий здійснює підготовку здобувачів вищої освіти, є такі:

- високий рівень фахових знань із предмета викладання та обізнаності щодо наукових новин у відповідній галузі наук;

- широкий науковий кругозір у суміжних галузях;

- знання андрагогіки як теорії навчання дорослих і сформованість дидактичної компетентності щодо ефективного застосування технологій їхнього навчання;

- уміння визначати й ураховувати рівень знань, умінь, навичок здобувачів вищої освіти, швидко коригувати обсяг і глибину їх занурення в предмет, тему;

- мобільність щодо формування змісту навчання, 3 урахуванням його цільового спрямування, а також досвіду діяльності й індивідуальних інтересів і потреб здобувачів;

- позитивні особистісні якості: комунікативна спрямованість, науковість, інтелігентність, доброзичливість, емпатійність, рефлективність, толерантність, почуття гумору тощо [1, с. 92].

Суттєво, що означені вище трансформації в дидактичній системі науково-педагогічних кадрів, які тяжіють до впровадження засобів андрагогічної парадигми вищої освіти, потребують певної професіоналізації їхніх особистісних якостей i дидактичних функцій діяльності. При цьому професіоналізація їхньої особистості як викладачів-андрагогів визначається певними модусами [5, с. 94], що позначають відповідний спосіб їхнього буття та дії в освітньо-науковому середовищі закладу вищої освіти, а також переживання й мислення, фіксуючи ті змінні властивості, які притаманні їм у певних станах здійснення науково-педагогічної діяльності. Серед них найчастіше виділяються такі модуси професіоналізації: 
- модус вибору, який визначає можливості свідомого вибору викладачем як суб'єктом андрагогічної взаємодії зі здобувачами вищої освіти ціннісних засад, змісту, форм, методів навчання, а також способів діагностування й контролю його прикінцевих результатів. Навчання здобувачів вищої освіти як дорослих, упродовж якого вони мають стати партнерами в спільній діяльності 3 викладачем-андрагогом, передбачає впровадження різноманітних гнучких програм із дотриманням принципів самореалізації, творчості, свободи самовираження, практичного застосування знань, що потребує застосування активних методів організації навчально-пізнавальної та навчально-професійної діяльності, які дають змогу моделювати ситуації з практики, створювати атмосферу творчості в групі;

- модус соціального впливу, що акцентує необхідність розвитку професійної самосвідомості викладача як андрагога, який, ураховуючи інноваційні зміни освітньо-наукового середовища, має осягнути цінність особистості здобувача вищої освіти в контексті загальнолюдських і культурних цінностей. Це потребує своєчасного застосування засобів фасилітації з метою створення сприятливих, мотивуючих і стимулюючих освітніх ситуацій, які сприяють розвитку й самореалізації кожної особистості та групи, досягненню ними успіху;

- модус діяльності, який, розкриваючи закономірності розвитку професіоналізму особистості й діяльності викладача як андрагога, указує на необхідність удосконалення його професійних вмінь і навичок з метою поступового переходу від допрофесійного рівня до майстерності й творчості. Стратегія професійного становлення й розвитку викладача як андрагога в процесі здійснення науково-педагогічної діяльності в закладі вищої освіти проходить спочатку етап унесення новизни в окремі складники його компетентності, потім - етап активного вдосконалення практичного досвіду й прагнення презентувати його колегам, на завершальному - етапі інноваційний змін - спостерігається не просто додавання новизни до вже відомих прийомів, методів, технологій, а створення принципово нових інтелектуальних $\mathrm{i}$ дидактико-методичних продуктів;

- модус перспектив і трансформацій, який відкриває можливості особистісного й професійного розвитку викладача як андрагога через розши- рення його комунікативно-рольових функцій та опанування відповідним дидактичним арсеналом засобів, щоб виконувати роль консультанта, експерта, коуча, дорадника для аудиторії та осіб, із якими він працює. Це потребує трансформаційних змін в особистості викладача як андрагога, оскільки він має виявити готовність до опанування вказаних ролей і функцій, постійно вдосконалювати способи їх реалізації;

- модус циклічності, що орієнтує професійну діяльність викладача як андрагога на врахування змінюваності певних періодів в освіті здобувачів вищої освіти як дорослих, які досягають відповідних ступенів - магістра та доктора філософії, підготовка яких здійснюється за відповідними «андрагогічними циклами» [9, с. 234], віддзеркалюючи, отже, траєкторію їхнього безперервного навчання.

Висновки. За нашими спостереженнями, організація освітньо-наукового процесу в сучасному закладі вищої освіти на засадах андрагогічної парадигми вимагає передусім зміни комунікативних ролей і відповідного дидактичного функціоналу науково-педагогічної діяльності викладачів, які здійснюють підготовку здобувачів вищої освіти магістерського й докторського рівнів. Зумовлено це тим, що викладач як андрагог не просто передає знання студентам магістратури й аспірантам, а створює сприятливі психолого-педагогічні умови, щоб вони мали можливість працювати зі своїм досвідом, розвивати інтелектуально-творчі, комунікативні, лідерські та організаторські здібності, планувати й оцінювати якість власної навчально-пізнавальної, професійної та дослідницької діяльності, самостійно й виважено приймати рішення й нести відповідальність за них тощо.

Отже, приєднання України до реалізації принципів Болонської декларації (утворення єдиного ринку праці вищої кваліфікації в Європі, забезпечення якісного освітнього рівня фахівців і відповідності їх підготовки умовам міжнародного ринку праці) посилює актуальність проблеми формування андрагогічної компетентності у викладацького складу науково-педагогічного персоналу вітчизняних закладів вищої освіти, тому традиційна роль викладачів як трансляторів знань трансформується в їхню місію як наставників, тьюторів, фасилітаторів, медіаторів, модераторів.

\section{Література}

1. Гибаддулина Ю.М. Развитие ролевой позиции будущего педагога в образовательном процессе вуза : дисс. ... канд. пед. наук : 13.00.08. Омск, 2016. 308 с.

2. Концепція розвитку освіти України на період 2015-2025 pp. : Проект. URL: http://www.tnpu.edu.ua/ EKTS/proekt_koncepc.pdf.

3. Особистісний і професійний розвиток дорослих: теорія і практика : монографія / заг. ред. О.В. Аніщенко. Київ : ІПООД НАПН України, 2016. 200 с. 
4. Скрипник M.I. Дослідження проблем професіоналізму науково-педагогічних працівників. Проблеми освіти. 2015. № 83. Ч. ІІ. С. 194-199.

5. Сорочан Т.М. Місія та функції андрагогів у системі післядипломної педагогічної освіти. Післядипломна освіта в Украӥні. 2012. № 2 (21). С. 92-96.

6. Сорочан Т.М. Фасілітація - нова функція післядипломної педагогічної освіти. Освіта на Луганщині. 2004. № 2 (21). С. 8-11.

7. Цокур О.С. Підготовка нового покоління науково-педагогічних кадрів як найважливіша місія класичного університету в умовах глобалізації. Університетська педагогічна освіта: історія, теорія $i$ перспективи розвитку в умовах глобалізаиії : колективна монографія / під. ред. О.С. Цокур. Одеса : ФОП Бондаренко О.М., 2018. С. 47-58.

8. Brown D.H. Teaching by Principles. An Interactive Approach to Language Pedagogy. 4th edition. NY : Pearson Education, 2015. 280 p.

9. Jarvis P. Adult Education and Lifelong Learning. Theory and practice. 3rd. edn. London : Routledge, 2004. $374 \mathrm{p}$.

10. Khoronko L., Tskvitariya T. The role of the chair of pedagogy in realization the strategy of vocational and educational training of medical university teachers. Modern European Researche. 2014. № 2. C. 50-53.

11. The Lisbon Strategy. Access mode. URL: http://circa.europa.eu/irc/opoce/factsheets/info/data/policies/ lisbon/article_7207_en.htm.

12. Wrench J.S., Richmond V.P., Gorham J. Communication Affect \& Learning in the Classroom: 3rd Edition. Tapestry Press, MA. USA, 2001. 227 p.

\section{References}

1. Gibaddulina Ju. M. (2016) Razvitie rolevoj pozicii budushhego pedagoga v obrazovatelnom processe vuza [Development of the role position of the future teacher in the educational process of the university] (PhD Thesis), Omsk: Omsk National University (in Russian).

2. Koncepciya rozvytku osvity Ukrayiny na period 2015-2025 rr. [The concept of development of education in Ukraine for the period 2015-2025] Proekt. URL: http://www.tnpu.edu.ua/EKTS/proekt_koncepc.pdf (in Ukrainian).

3. Anishhenko O.V. (ed.) (2016) Osobystisnyj i profesijnyj rozvytok doroslyx: teoriya i praktyka [Personal and professional development of adults: theory and practice]. Kyiv: IPOOD NAPN (in Ukrainian).

4. Skrypnyk M.I. (2015) Doslidzhennya problem profesionalizmu naukovo-pedagogichnyx pracivnykiv [Research of problems of professionalism of scientific and pedagogical workers]. Problemy osvity. N 83. Ch. II. S. 194-199 (in Ukrainian).

5. Sorochan T.M. (2012) Misiya ta funkciyi andragogiv u systemi pislyadyplomnoyi pedagogichnoyi osvity [Mission and functions of andragogues in the system of postgraduate pedagogical education]. Pislyadyplomna osvita v Ukrayini. N 2(21). S. 92-96 (in Ukrainian).

6. Sorochan T.M. (2004) Fasilitaciya - nova funkciya pislyadyplomnoyi pedagogichnoyi osvity [Facilitation is a new function of postgraduate pedagogical education]. Osvita na Luganshhyni. № 2 (21). S. 8-11 (in Ukrainian).

7. Czokur O.S. (2018) Pidgotovka novogo pokolinnya naukovo-pedagogichnyx kadriv yak najvazhlyvisha misiya klasychnogo universytetu $\mathrm{v}$ umovax globalizaciyi [Training of a new generation of scientific and pedagogical staff as the most important mission of the classical university in the context of globalization]. Universytetska pedagogichna osvita: istoriya, teoriya i perspektyvy rozvytku v umovax globalizaciyi. Odesa: FOP Bondarenko O.M. S. 47-58 s. (in Ukrainian).

8. Brown D.H. (2015) Teaching by Principles. An Interactive Approach to Language Pedagogy : 4th edition. NY: Pearson Education. 280 p.

9. Jarvis P. (2004) Adult Education and Lifelong Learning. Theory and practice. 3rd. edn. London: Routledge. $374 \mathrm{p}$.

10. Khoronko L., Tskvitariya T. (2014) The role of the chair of pedagogy in realization the strategy of vocational and educational training of medical university teachers. Modern European Researche. № 2. C. 50-53.

11. The Lisbon Strategy. Access mode. URL: http://circa.europa.eu/irc/opoce/factsheets/info/data/policies/ lisbon/article_7207_en.htm.

12. Wrench J.S., Richmond V.P., Gorham J. (2001) Communication Affect \& Learning in the Classroom: 3rd Edition.Tapestry Press, MA. USA. 227 p. 